\title{
IMPLEMENTASI KEBIJAKAN PROGRAM BERAS \\ SEJAHTERA (RASTRA) DI WILAYAH DESA MULYASARI \\ KECAMATAN PAMANUKAN KABUPATEN SUBANG
}

\author{
Ade Nawawi ${ }^{1}$ \\ Fakultas Ilmu Administrasi Universitas Subang \\ adenawawi15.an@gmail.com
}

Conelis Deda ${ }^{2}$

STFT GKI I.S. Kijne Jayapura

corbath58@gmail.com

\begin{abstract}
Abstrak
Penanggulangan kemiskinan merupakan kebijakan yang dilakukan terhadap masyarakat yang tidak mempunyai atau mempunyai sumber mata pencaharian dan tidak dapat memenuhi kebutuhan yang layak bagi kemanusiaan. Banyak upaya yang dilakukan oleh pemerintah untuk mengatasi masalah kemiskinan ini, melalui Program Beras sejahtera (Rastra). penyaluran beras sejahtera di Desa Mulyasari ditemukan permasalahan-permasalahan Kualitas beras sejahtera yang disalurkan ke Desa Mulyasari masih kurang layak, Belum adanya keseimbangan antara kuota beras dengan RTSPM, Penelitian ini diharapkan dapat mengetahui Implementasi Program Rastra di Desa Mulyasari Kecamatan Pamanukan Kab. Subang. Penelitian yang dilakukan bersifat deskriptif yaitu untuk mendapatkan data yang objektif dalam rangka mengetahui dan memahami Implementasi Program Rastra di Desa Mulyasari Kecamatan Pamanukan Kab. Subang Adapun informan perangkat desa Mulayasari, dan Masyarakat terkait. Berdasarkan penelitian diketahui Implementasi Program Beras sejahtera (Rastra) di Desa Mulyasari Kecamatan Pamanukan Kabupaten Subang belum berjalan dengan optimal Pada dimensia isi Kebijakan (Content of Policy), implementasi Program Beras sejahtera (Rastra) di Desa Mulyasari Kecamatan Pamanukan Kabupaten Subang tidak tunggangi oleh kepentingan perorangan melain suatu cita-cita dalam pengetansan kemiskinan kemudian masyarakat target program meresa terbantu dengan adanya program ini, untuk menghindari konflik social di masyarakat maka pemerintah desa dan jajaran membagi rata beras rastra tersebut sehingga jumlah beras yang dibagikan tidak sesuai dengan jumlah yang ditentukan pemerintah pemerintah belum mampu mengatasi keterlambatan pembayaran beras sejahtera petugas pelaksana program tidak mengantisipasi pembayaran yang macet dari program beras sejahtera, serta terakhir kurangnya kompetensi dan tanggung jawab dari pelaksana program Kemudian pada dimensi Lingkungan Kebijakan dukung oleh seluruh stakeheolder desa mulyasari, adanya ketegasan dari pemerintah sehingga beras sejahtera tepat sasaran serta masyarakat sering menerima Rastra dengan kualitas sangat rendah dan tidak layak dikonsumsi.
\end{abstract}

Kata Kunci : Implementasi, Beras Sejahtera 


\begin{abstract}
Poverty alleviation is a policy that is carried out on people who do not have or have a source of livelihood and cannot meet the proper needs of humanity. Many attempts were made by the government to overcome this problem of poverty, through the Poor Rice Program (Rastra). distribution of poor rice in Mulyasari Village found problems Quality of poor rice distributed to Mulyasari Village was still inadequate, There was no balance between the rice quota and RTSPM, this research was expected to find out the Implementation of the Literature Program in Mulyasari Village, Pamanukan District, Kab. Suban. The research conducted is descriptive in nature to obtain objective data in order to know and understand the Implementation of the Literature Program in Mulyasari Village, Pamanukan District. Subang The informants of the Mulayasari village apparatus, and the community concerned. Based on the research, it is known that the implementation of the Poor Rice Program (Rastra) in Mulyasari Village, Pamanukan Sub-District, Subang Regency has not been running optimally. other than an ideal in poverty alleviation then the target community of the program feels helped by the existence of this program, to avoid social conflict in the community, the village government and the ranks of the Rastra rice evenly distributed so that the amount of rice distributed is not in accordance with the amount determined by the government the government has not been able to overcome the late payment of poor rice program implementers do not anticipate bad payments from the poor rice program, and finally the lack of competence and responsibility of program implementers Then in the Environmental dimension Policy is supported by cells Told the Mulyasari village stakeheolder, there is a firmness from the government so that poor rice is right on target and the community often receives Rastra with very low quality and is not suitable for consumption.
\end{abstract}

Keywords: Implementation, Prosperous Rice

\title{
Pendahuluan
}

Konsep pembangunan sosial juga dapat dilihat kaitannya dalam rangka upaya mewujudkan cita-cita negara Kesejahteraan (Welfare State). Konsep tersebut bersumber dari pemahaman tentang fungsi negara. Dalam Welfare State, negara tidak lagi hanya bertugas memelihara ketertiban dan menegakkan hukum, tetapi terutama adalah meningkatkan kesejahteraan warganya. Dalam pandangan tersebut, negara dituntut untuk berperan aktif dalam mengusahakan kesejahteraan rakyatnya, yang didorong oleh pengakuan atau kesadaran bahwa rakyat berhak memperoleh kesejahteraan sesuai harkat dan martabatnya sebagai manusia. Dalam banyak hal, hak rakyat untuk memperoleh kesejahteraan ini juga akan terkait dengan hak-hak asasi manusia. Di Indonesia sendiri upaya penanggulangan kemiskinan itu tercantum dalam tujuan negara (Pembukaan UUD 1945) dan secara lebih spesifik dimuat dalam Undang-undang Nomor 11 tahun 2009 pasal 19,20,21 tentang Penanggulangaan Kemiskinan yang isinya : Penanggulangan kemiskinan merupakan kebijakan, program dan kegiatan yang dilakukan terhadap orang, keluarga, kelompok dan / atau masyarakat yang tidak mempunyai atau mempunyai sumber mata pencaharian dan tidak dapat memenuhi kebutuhan yang layak bagi kemanusiaan. 
Di tahun 2007 angka kemiskinan di Indonesia berkembang pesat, dan makin tak terkendali. Dari data pemerintah jumlah masyarakat miskin tercatat $17,75 \%$ dari 222 juta jiwa jumlah penduduk Indonesia. Sedangkan LIPI (Lembaga Ilmu Pengetahuan Indonesia) memperkirakan masyarakat miskin akan bertambah hingga 45,7 juta jiwa. Meningkatnya angka kemiskinan salah satunya disebabkan oleh adanya krisis ekonomi yang berkepanjangan. Krisis ekonomi tentu saja berdampak pada perekonomian yang ada. Banyak perusahaan yang tidak mampu bertahan sehingga harus gulung tikar di tengah jalan. Hal tersebut tentu saja akan berimbas pada adanya PHK (Pemutusan Hubungan Kerja) yang tidak terbatas jumlahnya. Secara otomatis ini mempengaruhi perekonomian masyarakat. Dampak yang lain adalah sulitnya mencari lapangan kerja baru untuk dapat memperoleh penghasilan guna mencukupi kebutuhan hidup. Akibatnya banyak muncul pengangguran yang jumlahnya tidak dapat dikontrol dan kemudian menambah jumlah masyarakat miskin di Indonesia.

Banyak upaya yang dilakukan oleh pemerintah untuk mengatasi masalah kemiskinan ini, melalui Program Beras sejahtera (Rastra). Program Rastra sebenarnya merupakan sebagian dari usaha pemerintah yang dilakukan guna menanggulangi masalah kemiskinan. Namun dalam prakteknya terdapat beberapa permasalahan antaralain dapat dilihat dari indikator tepat sasaran, yang dimana masih ditemukan Exclusion Error dan Inclusion Error yang tinggi. Exclusion error misalnya, masih terdapat rumah tangga yang seharusnya menerima Rastra, akan tetapi tidak terdaftar menjadi penerima Rastra, sehingga masyarakat tidak mendapat bantuan sosial Rastra tersebut. Sementara, Inclusion Error sebaliknya, yaitu terdapat rumah tangga yang tidak berhak untuk menerima Rastra, justru menerima bantuan tersebut. indikator tepat jumlah masih banyak terdapat Rumah Tangga Sasaran Penerima Manfaat (RTSPM) yang hanya menerima 4-6 kg per-bulan dari yang seharusnya sebanyak $15 \mathrm{~kg}$ per-bulan. Selain itu, RTS-PM juga harus membayar bahan pangan (terutama beras) lebih mahal dari yang seharusnya, yaitu Rp 1.600 per-kg. untuk indikator tepat waktu masih sering terjadi keterlambatan dalam pendistribusian bahan pangan, yang dimana pendistribusian tersebut seharusnya dilakukan setiap bulan.

Kecamatan Pamanukan adalah salah satu Kecamatan yang ada di Kabupaten Subang, dan merupakan Kecamatan kota dan letaknya paling dekat dengan Pusat Pemerintahan Kabupaten Subang, dalam segala bidang Kecamatan Pamanukan selalu menjadi tolak ukur keberhasilan program bagi Kecamatan-kecamatan lain. Kecamatan Pamanukan memiliki 9 Desa salah satunya Desa Mulyasari, Desa Mulyasari merupakan salah satu desa yang menerima kuota beras rastra yang cukup banyak dibandingan 8 desa lainnya di Kecamatan Pamanukan. Di Desa Mulyasari sebagian masyarakatnya masih miskin dan mata pencahariannya hanya sebagai petani biasa, buruh harian, buru mengelola lahan orang, pengangkut barang di pasar, tukang ojek, tukang cuci dan lain-lain, dan pekerjaan itu tidak bisa dijadikan untuk memenuhi kebutuhan mereka secara layak dan mencukupi kebutuhan makan seharihari. Dari pekerjaan mereka juga tidak bisa mendapatkan penghasilan yang tetap, karena pekerjaan itu hanya sewaktu-waktu. Tergantung dari ada dan tidaknya orang yang membutuhkannya jasa mereka. Desa Mulyasari memiliki rumah tangga sasaran pene7ima manfaat (RTS-PM) sebanyak 653, RTS-PM tersebut pada bulan Januari s.d Mei Tahun 2019 mendapat masing-masing $13 \mathrm{~kg}$ dengan total keseluruhan $8.489 \mathrm{~kg}$ 
dan bulan Juni s.d Desember tahun 2019 masing-masing mendapat $15 \mathrm{~kg}$ dengan total $9.795 \mathrm{~kg}$. Beras sejahtera tersebut di order dari Sub Bulog Divre Jawa Barat. Rumah Tangga Sasaran Penerima Manfaat Rastra (RTS-PM) sebanyak 653 Kepala Keluarga tersebut tersebar di 14 RW dan 42 RT

Dalam observasi awal dalam penyaluran beras sejahtera di Desa Mulyasari ditemukan permasalahan-permasalahan sebagai berikut:

1. Kualitas beras sejahtera yang disalurkan ke Desa Mulyasari masih kurang layak, beras yang diterima RTSPM beras berkualitas rendah yaitu berbau apek, berkutu dan berwarna kurning.

2. Belum adanya keseimbangan antara kuota beras dengan RTSPM, yang menerima Rastra hanya 653 orang sedangkan jumlah yang seharusnya menerima diperkirakan ada 800 RTSPM. Masing-masing RTSPM mendapat 15 kilo gram per kepala keluarga, Desa Mulyasari hanya mendapat jatah 9.795 kilo gram beras Rastra, Desa Mulyasari masih kekurangan Rastra sebanyak 2.205 kg untuk 147 RTSPM. Yang menetapkan kuota adalah bagian Administrasi Perekonomian Setda Kabupaten Subang dengan Keputusan Bupati Subang, didasarkan pada Pagu Rastra Kabupaten Subang, data RTS Kecamatan Desa Mulyasari dari BPS Kabupaten Subang.

3. Pada tahun 2017 Desa Mulyasari ada kendala dalam melakukan Pembayaran rastra, sehingga Camat Subang mendapatkan teguran dari Asisten Perekonomian Pembangunan Setda Kab. Subang tentang Penyelesaian Tunggakan Rastra 2019. Karena adanya kendala pembayaran rastra tersebut Desa Mulyasari dalam pendistribusian rastra nya pada tahun 2019 hanya melaksanakan 5 kali pendistribusian Rastra. Keterlambatan pembayaran dan pendistribusian Rastra serta kualitas beras rastra di Desa Mulyasari Kecamatan Pamanukan merupakan suatu permasalahan dari sebuah implementasi kebijakan, dalam hal ini hambatannya bisa dari berbagai faktor termasuk lingkungan. Apa saja kendala yang dihadapi oleh aparat Desa Mulyasari dalam Pelaksanaan Program Rastra di wilayahnya.

\section{Kerangka Teori}

\section{a. Implementasi Kebijakan}

Heinz Eulau dan Kenneth Prewitt (dalam Agustino:2008), dalam perspektif mereka mendefenisikan kebijakan publik sebagai : "keputusan tetap' yang dicirikan dengan konsistensi dan pengulangan (repitisi) tingkah laku dari mereka yang membuat dan dari mereka yang mematuhi keputusan tersebut." Defenisi lain mengenai kebijakan publik pun ditawarkan oleh Carl Frederich (dalam Agustino:2008), yang mengatakan bahwa kebijakan adalah "serangkaian tindakan atau kegiatan yang diusulkan oleh seseorang, kelompok, atau pemerintah dalam suatu lingkungan tertentu dimana terdapat hambatan-hambatan (kesulitan-kesulitan) dan kemungkinan-kemungkinan (kesempatan-kesempatan)dimana kebijakan tersebut diusulkan agar berguna dalam mengatasinya untuk mencapai tujuan yang dimaksud". Untuk maksud dari kebijakan sebagai bagian dari kegiatan, Federich menambahkan ketentuannya bahwa kebijakan tersebut berhubungan dengan penyelesaian beberapa maksud atau tujuan. Meskipun maksud atau tujuan dari 


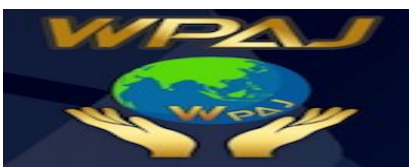

kegiatan pemerintah tidak selalu mudah untuk dilihat, tetapi ide bahwa kebijakan melibatkan perilaku yang mempunyai maksud, merupakan bagian penting dari defenesi kebijakan. Bagaimanapun juga kebijakan harus menunjukkan apa yang sesungguhnya dikerjakan daripada apa yang diusulkan dalam beberapa kegiatan pada suatu masalah.

Implementasi adalah Tindakan yang dilakukan baik oleh individu atau pejabat - pejabat atau kelompok - kelompok pemerintah atau swasta yang diarahkan untuk tercapainya tujuan yang telah digariskan dalam keputusan kebijakan (Van Meter dan Van Horn, 1975). Implementasi (implementation) menurut Kamus Ilmiah Populer mempunyai arti pelaksanaan atau penerapan Implementasi kebijakan publik sebagai "getting the job done and doing it". Dalam melaksanakan implementasi kebijakan menuntut adanya syarat antara lain adanya orang atau pelaksana, uang, dan kemampuan organisasional. Implementasi dalam hal ini merupakan proses mendapatkan sumber daya tambahan, sehingga dapat menghitung apa yang harus dikerjakan. Apa yang dikemukakan diatas paling tidak kebijakan memerlukan dua macam tindakan berurutan: pertama, merumuskan tindakan yang akan dilakukan; dan kedua, melaksanakan tindakan apa yang telah dirumuskan tadi.

Menurut Nugroho (2003:158), implementasi kebijakan pada prinsipnya adalah cara agar sebuah kebijakan dapat mencapai tujuannya (tidak lebih dan tidak kurang). Selanjutnya Nugroho (2003:158) mengemukakan bahwa perencanaan atau sebuah kebijakan yang baik akan berperan menentukan hasil yang baik. Konsep (yang didukung data dan informasi masa depan) kontribusinya mencapai proporsi sekitar 60 persen terhadap keberhasilan kebijakan tersebut dan proporsi sekitar 40 persen terhadap implementasi yang harus konsisten dengan konsep.

Berdasarkan hasil suatu penelitian diperoleh bahwa implementasi kebijakan merupakan hal yang krusial, karena dari konsep-konsep perencanaan, rata-rata konsistensi implementasi dicapai antara 10 persen sampai dengan 20 persen saja (Nugroho, 2003:158) Dalam implementasi kebijakan publik, terdapat dua pilihan langkah yang dapat dilakukan, yakni langsung mengimplementasikan dalam bentuk program-program atau melalui formulasi kebijakan derivat atau turunan dari kebijakan publik tersebut. Pada prinsipnya, kebijakan bertujuan untuk melakukan intervensi. Dengan demikian, implementasi kebijakan pada hakaketnya adalah tindakan (action) intervensi itu sendiri.

\section{Metode Penelitian}

Penelitian ini menggunakan pendekatan kualitaif. Menurut (2019:4) penelitian kualitatif merupakan metode-metode untuk mengeksplorasi dan memahami makna yang oleh sejumlah individu atau sekelompok orang dianggap berasal dari masalah sosial atau kemanusiaan. Proses penelitian ini melibatkan upaya-upaya penting seperti mengajukan pertanyaan-pertanyaan dan prosedur-prosedur mengumpulkan data spesifik dari partisipasi, menganalisis data secara induktif melalui tema-tema yang khusus ke tema-tema yang umum, dan menafsirkan makna dari data. Metode kualitatif ini juga dapat dikatakan berbasis pada informasi/kenyataan yang terjadi di lapangan. 


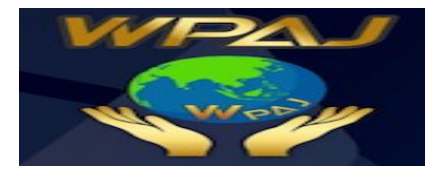

Volume 2 Issue 1, Juni 2020

http://ejournal.unsub.ac.id/index.php/Publik

\section{Hasil dan Pembahasan}

Rastra adalah Program Pemerintah dalam pemenuhan kebutuhan pangan bagi masyarakat miskin, yang sekaligus untuk mengurangi beban pengeluaran Rumah Tangga Miskin. Di samping itu dimaksudkan untuk meningkatkan akses masyarakat miskin dalam pemenuhan kebutuhan pangan pokok sebagai salah satu hak dasar masyarakat. Sasaran Program Rastra tahun 2019 adalah Rumah Tangga Sasaran (RTS) sesuai dengan hasil pendataan BPS tahun 2008 yang terdiri dari rumah tangga sangat miskin, rumah tangga miskin, rumah tangga hampir miskin dengan alokasi 13 $\mathrm{kg} / \mathrm{RTS} /$ bulan selama 12 bulan dengan harga Rp. 1.600/kg Netto di titik distribusi.

Sebelum tahun 1998 kebijakan pemerintah dalam bidang perberasan di Indonesia adalah memberikan subsidi kepada seluruh lapisan masyarakat baik yang miskin maupun yang mampu (general subsidy), namun sejak krisis ekonomi bulan Juli 1998 kebijakan subsidi beras diberikan khusus kepada kelompok masyarakat tertentu (Targeted Subsidy) melalui Operasi Pasar Khusus (OPK), yang kemudian berubah menjadi Rastra (beras bersubsidi untuk Rumah Tangga Miskin) pada tahun 2002, dengan perubahan kebijakan subsidi dari general targeted ke targeted subsidy, maka subsidi hanya diberikan kepada masyarakat miskin. Program Rastra di Desa Mulyasari merupakan program yang bersentuhan langsung dengan masyarakat, serta melibatkan berbagai pihak, yaitu aparat desa, lembaga musyawarah desa, LSM, serta tokoh masyarakat. Keberhasilan Program Rastra diukur berdasarkan Tingkat

Pencapaian Indikator 6 Tepat (6T), yaitu tepat sasaran, tepat jumlah, tepat harga, tepat waktu, tepat kualitas, dan tepat administrasi. Desa Mulyasari bukan satu-satunya Desa/Desa di Kabupaten Subang yang menunggak Rastra, seperti yang ditulis oleh surat kabar Satelit News edisi Kamis, 23 Desember 2018. Menurut surat kabar tersebut Kepala Bagian Ekonomi Pemkab Subang Ali Fahmi Sumanta, SH., M.Si. mengatakan tidak terserapnya beras untuk rakyat miskin (Rastra). Karena masih banyak desa atau desa di Kabupaten Subang yang menunggak. Untuk Desa/Desa yang menunggak bagian perekonomian tidak bias mendistribusikan Rastra. Namun bila ada pengajuan dari Desa dan sudah lunas tunggakan, bagian perekonomian akan langsung memproses tanpa memperlambat pengajuan tersebut. (Sumber : Surat Kabar Harian Satelit News Edisi Kamis, 23 Desember 2019, sumber terlampir).

Terkait tunggakan Rastra Pemerintah Kabupaten Subang tahun 2019 kepada Bulog Sub Divisi Regional Subang sebesar Rp. 1.825 miliar, DPRD Kabupaten Subang Komisi IV telah memanggil Kabag Perekonomian Pemkab Subang selaku koordinator Pelaksana Program Rastra tahun 2019. Tahun 201 Kabupaten Subang mendapat Kuota Rastra 22.917.240 kg dan akan disalurkan kepada 127.318 Kepala keluarga. (Sumber : Antara News Edisi Minggu, 6 Pebruari 2011, sumber terlampir)

Deskripsi data merupakan penjelasan mengenai data yang telah didapatkan dari hasil penelitian lapangan. Dalam penelitian ini peneliti menggunakan Teori Model Implementasi Kebijakan menurut Merilee $S$ Grindle. Teori tersebut menejlaskan bahwa keberhasilan Implementasi Kebijakan Publik dapat diukur dari proses pencapaian hasil akhir (outcomes) yaitu tercapai atau tidaknya tujuan yang dingin diraih. Variabel-variael yang mempengaruhi suatu implementasi yaitu :

1. Isi Kebijakan (content of policy)

a. Kepentingan-kepentingan yang mempengaruhi

b. Tipe manfaat 


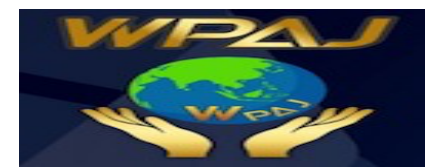

c. Derajat perubahan yang ingin dicapai

d. Letak pengambilan keputusan

e. Pelaksana program

f. Sumber daya yang digunakan

2. Lingkungan Kebij akan

a. Kekuasaan, kepentingan-kepentingan dan strategi dari aktor yang terlibat

b. Karakteristik lembaga dan rezim yang berkuasa

c. Tingkat kepatuhan dan adanya respon dari pelaksana

Mengingat bahwa jenis dan analisis data yang digunakan dalam penelitian ini adalah penelitian kualitatif, maka data yang diperoleh bersifat deskriptif berbentuk kata dan kalimat dari hasil wawancara, hasil observasi lapangan serta data hasil dokumentasi lainnya.

Dengan menggunakan teknik data kualitatif menggunakan konsep yang diberikan oleh Merilee S Grindle, data-data tersebut dianalisis selama proses penelitian berlangsung. Data yang diperoleh dari hasil penelitian lapangan melalui wawancara, dokumentasi, maupun observasi dilakukan reduksi untuk dapat mencari tema dan polanya yang diberikan kode-kode pada aspek tertentu berdasarkan jawaban yang sama dan berkaitan dengan pembahasan masalah penelitian serta dilakuan kategorisasi dalam penyusunan jawaban penelitian, peneliti memberikan kode pada aspek tertentu :

Berdasarkan teori tersebut berikut ini kategori yang disusun oleh peneliti berdasarkan hasil penelitian di lapangan, yaitu : Implementasi Program Beras sejahtera (Rastra) di Desa Mulyasari Kecamatan Pamanukan Kabupaten Subang tahun 2019, dipengaruhi oleh :

1. Isi Kebijakan (Content of Policy)

Indikatornya meliputi :

a. Kepentingan-kepentingan yang mempengaruhi

Apakah ada kepentingan-kepentingan yang mempengaruhi implementasi program rastra di Desa Mulyasari Kecamatan Pamanukan Kabupaten Subang.

b. Tipe Manfaat

Manfaat apa yang dirasakan oleh warga miskin Desa Mulyasari Kecamatan Pamanukan Kabupaten Subang dengan digulirkannya Program Rastra oleh Pemerintah Pusat.

c. Derajat perubahan yang ingin dicapai

Dengan digulirkannya program Rastra ke daerah-daerah derajat perubahan apa yang ingin dicapai oleh pemerintah.

d. Letak Pengambilan Keputusan

Keputusan apa yang diambil jika terjadi keterlambatan dalam pembayaran

Rastra di Desa Mulyasari Kecamatan Pamanukan Kabupaten Subang.

e. Pelaksana program

Siapa saja yang melaksanakan program Rastra di tingkat Kabupaten Subang sampai dengan tingkat Desa Mulyasari.

f. Sumber daya yang digunakan

Bagaimana sumber daya aparatur Desa Mulyasari 


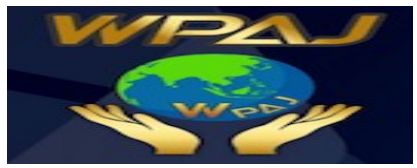

2. Lingkungan Kebijakan (Contex of policy)

a. Kekuasaan, kepentingan-kepentingan dan strategi dari aktor yang terlibat untuk mensukeskan Program Rastra di Desa Mulyasari Kecamatan Pamanukan Kabupaten Subang strategi apa yang dilakukan oleh Camat Pamanukan agar Desa Mulyasari dapat mengatasi keterlambatan pembayaran rastranya, agar pendistribusian Rastra di Desa Mulyasari Kecamatan Pamanukan Kabupaten Subang lancar dan tidak terlambat. Sedangkan untuk Desa Mulyasari strategi apa yang akan dilakukan agar pembayaran rastranya tidak ada hambatan.

b. Kerakteristik lembaga dan rezim yang berkuasa

Bagaimana karakteristik Desa Mulyasari sehingga pembayaran Rastra di desa ini terlambat, dan bagaimana karakteristik dari Kepala Desa Mulyasari serta aparaturnya.

c. Tingkat kepatuhan dan adanya respon dari pelaksana

Bagaimana tingkat kepatuhan dan respon aparatur Desa Mulyasari dalam pelaksanaan Program Rastra di wilayah Desa Mulyasari Kecamatan Pamanukan Kabupaten Subang pada tahun 2019, serta faktor pendukung dan penghambat Program Rastra di Desa Mulyasari Kecamatan Pamanukan Kabupaten Subang.

Implementasi Program Beras sejahtera (Rastra) di Desa Mulyasari Kecamatan Pamanukan Kabupaten Subang tahun 2019 dipengaruhi oleh :

Isi Kebijakan (Content of Policy)

\section{Kepentingan-kepentingan yang mempengaruhi}

Menurut Informan Desa, kepentingan-kepentingan yang mempengaruhi Kecamatan Pamanukan Kabupaten Subang tahun 2019 adalah : "Secara political mengacu pada isu strategis pengentasan kemiskinan melalui visi dan misi Kabupaten Subang yaitu tentang kesejahteraan rakyat, dengan digulirkannya program- program pemerintah, untuk pengentasan kemiskinan, salah satunya adalah Program Beras sejahtera, agar kesejhateraan warga miskin dapat terangkat. Implementasi Program Rastra yang dikejar bukan kepentingan, karena yang dikejar kepentingan akan ada kesenjangan-kesenjangan antara tujuan Program Rastra daengan Stakeholder di pemerintahan". Implementasi adalah pelaksanaan teknis di lapangan. Teori di lapangan RTS-PM mendapat $15 \mathrm{~kg}$. tetapi dikarenakan jumlah RTS-PM lebih banyak dari kuota ada kebijakan lain berdasarkan musyawarah masyarakat di Desa Mulyasari RTS-PM hanya mendapat $13 \mathrm{~kg}$ itu untuk kesejahteraan masyarakat Desa Mulyasari bukan kepentingan camat. Jadi bahwa kepentingan-kepentingan yang mempengaruhi implementasi Program Beras sejahtera (Rastra) di Desa Mulyasari Kecamatan Pamanukan Kabupaten Subang secara politikal di lapangan adalah melalui isu strategis pengentasan kemiskinan yang bertujuan mengurangi beban pengeluaran Rumah Tangga Miskin dalam pemenuhan kebutuhan pangan pokok yaitu beras melalui pendistribusian beras bersubsidi sebanak $156 \mathrm{Kg} / \mathrm{RTS}$ per tahun atau setara dengan $13 \mathrm{~kg}$ per RTS per bulan dengan harga tebus Rp. 1600 per kilogram netto di titik distribusi Camat dan Kepala Desa tidak mempunyai kepentingan apapun dalam penyaluran beras Rastra. Menurut Grindle, Interst affected berkaitan dengan berbagai kepentingan yang mempengaruhi suatu implementasi kebijakan. 


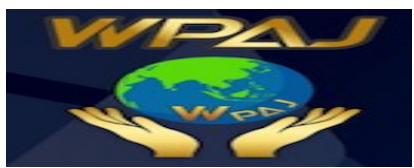

Indikator ini berargumen bahwa suatu kebijakan dalam pelaksanaannya pasti melibatkan banyak kepentingan, dan sejauh mana kepentingan-kepentingan tersebut membawa pengaruh terhadap implementasinya.

Jadi implementasi Program Beras sejahtera (Rastra) di Desa Mulyasari Kecamatan Pamanukan Kabupaten Subang dalam indkator kepentingan yang mempengaruhi telah opimal karena tidak tunggangi oleh kepentingan perorangan melain suatu citacita dalam pengetansan kemiskinan

\section{Tipe Manfaat}

Menurut Informan Desa, manfaat yang dirasakan oleh warga miskin Desa Mulyasari Kecamatan Pamanukan Kabupaten Subang dengan digulirkannya Program Rastra oleh Pemerintah Pusat adalah : "Dengan digulirkannya Program Rastra, kesejahteraan warga miskin dapat meningkat".

Berdasarkan pernyataan di atas jadi adalah Program Rastra ini sangat bermanfaat bagi warga miskin, mereka dapat membeli beras untuk mencukupi kebutuhan pokoknya yaitu beras dengan harga yang murah. Program Rastra ini sangat membantu RTS-PM untuk mengurangi beban Rumah Tangga mereka. Sedangkan menurut informan lainnya yaitu : "Rastra adalah salah satu Program Pemerintah untuk membantu masyarakat yang miskin dan Rawan Pangan agar mereka mendapatkan beras murah untuk kebutuhan mereka sehari-hari". Jadi pernyataan tersebut menguatkan pernyataan dari informan sebelumnya, yang menyatakan Program Rastra ini dapat meningkatkan kesejahteraan warga miskin, jika warga miskin dapat membeli beras berarti mereka dapat kesejahteraan karena kebutuhan pangan pokok mereka terpenuhi. Harga beras yang mahal membuat warga miskin tidak dapat membeli beras, akibatnya banyak warga miskin yang kelaparan, dengan digulirkannya Program Rastra yaitu beras bersubsidi dari pemerintah, warga miskin tersebut dapat membeli beras karena Rastra ini hanya Rp. $1.600 / \mathrm{kg}$ bersih di titik distribusi. Menurut Informan, “Warga RW 07 Dsn Bojong Curug sangat berterimakasih karena merasa terbantu, dan mengurangi beban mereka meskipun mendapat jatah Rastranya 1 bulan sekali, karena mata pencaharian masyarakat di RW 07 Pasir Kalapa kebanyakan petani, dan jika gagal panen mereka tidak dapat memiliki penghasilan dan yang mendapat Rastra tersebut kebanyakan adalah orang lanjut usia yang sudah tidak dapat bekerja."

Menurut Grindle, content of policy berupaya untuk menunjukkan atau menjelaskan bahwa dalam suatu kebijakan harus terdapat beberapa jenis manfaat yang menunjukkan dampak positif . dari pemafaran diatas diketahui bahwa implementasi Program Beras sejahtera (Rastra) di Desa Mulyasari Kecamatan Pamanukan Kabupaten Subang dalam indkator tipe manfaat telah optimal karena masyarakat target program meresa terbantu dengan adanya program ini.

\section{Derajat Perubahan yang ingin dicapai oleh Pemerintah}

Menurut Informan dengan digulirkannya Program Rastra ke daerah-daerah derajat perubahan apa yang ingin dicapai oleh pemerintah.

“Drajat perubahan yang ingin dicapai oleh pemerintah adalah agar beban pengeluran Rumah Tangga Miskin (RTM) berkurang, tujuannya meningkatkan akses masyarakat miskin untuk memenuhi kebutuhan pangan pokok, dan melakukan upaya 


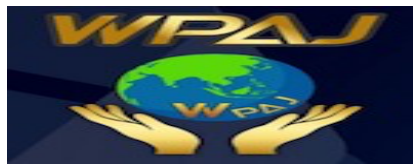

peningkatan pendapatan petani, ketahanan pangan, pengembangan ekonomi pedesaan serta stabilitas ekonomi nasional'.

Jadi dari pernyataan di atas adalah dengan digulirkannya Program Rastra ini pemerintah mengharapkan masyarakat miskin, petani dalam negeri khususnya di sektor pertanian dapat lebih sejahtera dan meningkat. Jika sektor pertanian meningkat maka ekonomi pedesaan berkembang dan stabilitas ekonomi nasional akan naik. Menurut Informan Desa, adalah : "Derajat perubahan yang ingin dicapai oleh masyarakat khususnya di Desa Mulyasari Kecamatan Pamanukan Kabupaten Subang adalah masyarakat lebih sejahtera, dan mereka tidak susah lagi membeli beras. Saya ingin masyarakat di Desa Mulyasari ini dapat membayar jatah Rastra mereka, agar mereka punya beras untuk makan sehari-hari".Jadi berdasarkan pernyataan di atas adalah RTSPM RW 05 Dsn Kedung Gede mempunyai keinginan yang sama dengan RTSPM RW 07 Dsn Bojong Curug yang mengharapkan Rastra tersebut pendistribusiannya lancar secepat-cepatnya minimal 1 minggu sekali Rastra tersebut bisa didistribusikan kepada masyarakat. Masyarakat juga mengharapkan perhatian dari Pemerintah untuk memberi perhatian kepada kualitas beras sejahtera yang didistribusikan oleh Bulog. Karena pada tahun 2019 beras Rastra tersebut berbau apek, berkutu dan berwarna kuning. Hal ini harus diperhatikan dalam angka meningkatkan taraf hidup dan kesehatan warga miskin. Menurut Informan Petugas, derajat perubahan yang ingin dicapai adalah:

“Jika kesejahteraan, kami merasa kesejahteraan kami tidak meningkat. Karena

Rastra tersebut hanya bisa memenuhi kebutuhan selama 2 hari saja. Kalau bisa kami sampaikan agar pendistribusianRastranya ditambah".

Jadi berdasarkan pernyataan di atas adalah pendapat yang dikemukakan oleh RTSPM RW 14 Dsn Bojong Curug sangat berbeda dengan pernyataan-pernyataan dari para informan sebelumnya. Beliau berpendapat bahwa Rastra ini hanya bias dikonsumsi selama 2 hari saja. Selebihnya mereka harus membeli lagi beras di pasar/warung. Karena jatah Rastra yang mereka terima sedikit yaitu $7.5 \mathrm{~kg}$ setiap pendistribusiannya. Karena jatah mereka harus dibagi dengan Rumah Tangga Miskin yang tidak mempunyai Kartu Rastra. Ini disebabkan karena kuota Rastra yang diturunkan di Desa Mulyasari lebih sedikit dari jumlah RTM nya yang memang banyak. Apalagi pekerjaan masyarakat Dsn Lumbung mayoritas petani kecil dan buruh tani.

Menurut Grindle, Extent of Change Envision (Derajat Perubahan yang Ingin Dicapai) adalah bahwa sejauh mana perubahan yang diinginkan dari sebuah kebijakan haruslah memiliki skala yang jelas. Jadi implementasi Program Beras sejahtera (Rastra) di Desa Mulyasari Kecamatan Pamanukan Kabupaten Subang dalam indkator derajat perubahan yang ingin dicapai belum optimal, karena untuk menghindari konflik social di masyarakat maka pemerintah desa dan jajaran membagi rata beras rastra tersebut sehingga jumlah beras yang dibagikan tidak sesuai dengan jumlah yang ditentukan pemerintah.

\section{Letak Pengambilan Keputusan}

Keputusan apa yang diambil jika terjadi keterlambatan dalam pembayaran Rastra di Desa Mulyasari Kecamatan Pamanukan Kabupaten Subang. Menurut Informan Pemerintah Kecamatan, jika terjadi terlambat pembayaran Rastra di 


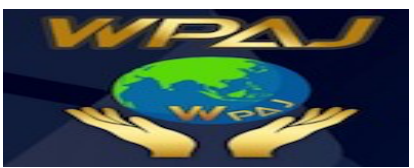

Kecamatan Pamanukan Kabupaten Subang adalah : "Melakukan pembinaan terhadap aparatur pemerintah mulai dari tingkat desa sampai ke tingkat RT, membuat surat teguran kepada Kepala Desa Mulyasari, evaluasi dan monitoring terhadap realisasi penyetoran Rastra'". Dari pernyataan tersebut jadi adalah camat sudah bertindak tegas agar Desa Mulyasari lebih meningkatkan kinerjanya selaku Pelaksana Distribusi karena Kepala Desa adalah penanggung jawab pendistribusian Rastra di wilayah Desa Mulyasari, selain itu Kepala Desa bertanggung jawab dalam penyelesaian pembayaran Harga Pokok Beras (HPB) serta administrasi distribusi Rastra. Jika terjadi kemacetan pembayaran Rastra Kepala Desa harus cek ke lapangan dimana pembayaran yang susah dan Camat Pamanukan sudah memerintahkan Kepala Desa Mulyasari untuk membicarakan hal ini dengan Forum RW di Desa Mulyasari, agar titik permasalahan macetnya pembayaran Rastra bisa ditemukan, dan dihasilkan solusi yang baik. Jika ada RW yang tidak jujur menyetorkan uang pembayaran Rastra nya agar bisa diganti oleh yang lain.

Sedangkan menurut Informan Desa, Jika terjadi kertelambatan dalam pembayaran Rastra di Desa Mulyasari Kecamatan Pamanukan Kabupaten Subang adalah : "Kita sudah evaluasi di lapangan, penyebab keterlambatan dalam pembayaran Rastra ini memang karena faktor ekonomi RTS-PM kurang, mereka diberi tempo 1 minggu untuk melunasi Rastra ke RT masing-masing tapi dalam jangka 1 minggu itu ada saja yang belum melunasi, ada RW yang mau menanggulangi dulu pembayaran Rastra RTS-PMnya, tapi ada yang tidak bisa juga. Saya juga sudah memanggil RT dan RW di Desa Mulyasari untuk melaporkan pendistribusian di wilayah RT/RW masing-masing?". Jadi dari pernyataan Informan Desa di atas adalah kepala desa sudah melakukan evaluasi dan monitoring di RT dan RW Desa Mulyasari, Kepala Desa juga sudah melakukan rapat intern dengan RT dan RW di Desa Mulyasari. Penyebab keterlambatan ini adalah dari faktor ekonomi masyarakatnya dalam melunasi Rastra di wilayahnya RT/RW ada RW yang mau menanggulangi dulu Rastra untuk RTSPM di wilayah RT/RW nya tapi ada yang tidak bias menanggulangi, menurut penulis alangkah baiknya jika Rastra untuk RTSPM ini digratiskan oleh pemerintah pusat, agar warga miskin benar-benar dapat menerima bantuan dari pemerintah dan kesejahteraannya dapat terangkat.

Menurut grindle, Pengambilan keputusan dalam suatu kebijakan memegang peranan penting dalam pelaksanaan suatu kebijakan, maka pada bagian ini harus dijelaskan dimana letak pengambilan keputusan dari suatu kebijakan yang akan diimplementasikan. Implementasi Program Beras sejahtera (Rastra) di Desa Mulyasari Kecamatan Pamanukan Kabupaten Subang dalam indkator letak pengambilan keputusan dicapai belum optimal karena pemerintah belum mampu mengatasi keterlambatan pembayaran beras sejahtera.

\section{Pelaksana Program}

Siapa saja yang melaksanakan Program Rastra di tingkat Kabupaten Subang sampai dengan tingkat Desa Mulyasari. Menurut Informan Desa, yang melaksanakan Program Rastra di tingkat Kabupaten Subang sampai dengan tingkat Desa Mulyasari adalah : "Untuk tingkat Kabupaten Pelaksanaannya adalah Tim Koordinasi Rastra Kabupaten Subang yaitu bagian Administrasi, perekonomian Setda Kabupaten Subang, Tingkat Kecamatan Pamanukan, Pelaksana Programnya adalah Tim 


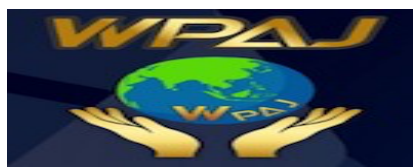

Koordinasi Rastra Kecamatan Pamanukan melalui Bagian Kesos Kecamatan Pamanukan. Sedangkan untuk tingkat desa dikelola oleh Desa Mulyasari selaku Pelaksana Pendistribusian Rastra di wilayah Desa Mulyasari di bawah naungan Kasi Kesos Desa Mulyasari Beras Rastra tersebut diterima dari Satuan Kerja Rastra yang bertanggung jawab kepada Perum Bulog Divisi Regional I Subang".

Jadi dari pernyataan di atas bahwa Desa Mulyasari selaku pelaksana distribusi di tingkat desa mempunyai wewenang untuk mendistribusikan Rastra kepada RTSPM, dan pembayaran Rastra serta administrasinya merupakan tanggung jawab Kepala Desa sepenuhnya, bilamana terjadi keterlambatan pembayaran Rastra seperti sekarang, seharusnya Kepala Desa Mulyasari mengadakan rapat intern dan mempertanyakan setoran dari tiap-tiap RT, dari situ akan terlihat RW dan RT mana saja yang belum melunasi pembayarannya. Sedangkan menurut Informan Masyarakat, tentang pembayaran Rastra : "Pendistribusian ke RTSPM Dsn Kedung Gede lancar, tetapi kalau belum puny a uang ditombokin dulu sama Pak RW, kemarin masih Rp. 300.000 yang belum dibayar oleh RTSPM ke Pak RW sampai sekarang masih ada yang belum membayar"

Menurut Informan Pemerintah Kecamatan, penyebab terlambatnya penyetoran yaitu : "Sistim kolektif yang belum maksimal, pembentukan Tim yang belum berkompeten, belum bekerja sesuai harapan, kesadaran RTSPM untuk membayar Rastra masih rendah, BOP Rastra belum maksimal, masih ditemukannya beras dengan kualitas rendah".

Dari pernyataan di atas, jadi penyebab ketelambatan pembayaran Rastra di keluahan Mulyasari disebabkan oleh faktor internal dan faktor eksternal. Faktor internalnya berasal dari aparatur desanya sendiri, aparatur Desa Mulyasari kurang semangat dalam bekerja menyalurkan Rastra di wilayahnya, karena Biaya Operasional (BOP) Rastra sangat kecil, yaitu sebesar Rp. 6 (enam rupiah) per kilogram, sedangkan factor eksternalnya adalah kondisi dan teknis di lapangan masih rendahnya ekonomi RTSPM.

Menurut Grindle, Program Implementer (Pelaksana Program) dalam menjalankan suatu kebijakan atau program harus didukung dengan adanya pelaksana kebijakan yang kompeten dan kapabel demi keberhasilan suatu kebijakan. Dalam implementasi Program Beras sejahtera (Rastra) di Desa Mulyasari Kecamatan Pamanukan Kabupaten Subang dalam indkator pelaksana program belum optimal, karena petugas pelaksana program tidak mengantisipasi pembayaran yang macet dari program beras sejahtera.

\section{Sumberdaya yang digunakan}

Menurut Informat Pemerintah kecamatan, sumber daya aparatur Desa Mulyasari : "Sumber daya aparatur Desa Mulyasari belum optimal yaitu belum menguasai pekerjaannya". Jadi dari pernyataan di atas adalah sumberdaya aparatur pemerintah sangat menentukan sukses dan tidaknya suatu kebijakan. Aparatur desa harus memiliki rasa tanggung jawab terhadap Program Pemerintah/Rastra yang bersentuhan langsung dengan masyrakat ini. Sebagai pelaksana distribusi desa harus memilih aparatur-aparatur yang memiliki loyalitas dan dedikasi yang tinggi dan mampu menyelesaikan pekerjaan yang diberikan kepadanya, karena implementasi Rastra ini adalah merupakan Program dari Pemerintah Pusat untuk warga miskin 


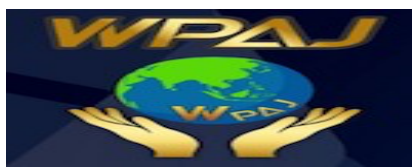

yang membutuhkan beras bersubsidi. Menurut Informan Desa, : "Sumberdaya aparatur Desa Mulyasari cukup baik, hanya masyarakatnya yang belum mampu, karena kami tidak menargetkan jumlah, tapi kami lebih menitik beratkan pada sasaran. Berapa sasaran RTS-PM yang sudah menerima Rastra, karena kami ingin tepat sasaran, Rastra ini benar-benar hanya dibeli oleh RTSPM, bukan kepada pihak lain yang ingin mengambil keuntungan". Jadi dari pernyataan di atas, Desa Mulyasari bertujuan baik, ingin benar-benar memberikan Rastranya hanya untuk RTSPM yang benar-benar membutuhkan. Tetapi segi pembayaran juga harus diupayakan lancar, karena jika pembayaran sering terlambat, maka pendistribusian Rastranya terlambat juga, pihak Sub Dolog Sub Divre III tidak bisa mengirimkan Rastra ke Desa Mulyasari sebelum pembayarannya dilunasi. Jika Rastra di Desa Mulyasari sering telat Pendistribusiannya maka yang dirugikan adalah warga miskin di Desa Mulyasari sendiri. Karena peneliti adalah Staf Kecamatan Pamanukan, mendapat pertanyaan sebagai berikut. Menurut Informan Masyarakat, mengenai keterlambatan Rastra : "Kenapa sekarang-sekarang ini rastra belum turun ya bu? Warga di RW saya sudah sering menanyakan kapan Rastra turunnya"

Dari pernyataan di atas sangat jelas bahwa masyarakat sangat mengharapkan Rastra cepat didistribusikan kembali, pihak desa seharusnya segera mencari solusi untuk menyelesaikan permasalahan ini. Menurut Grindle, Pelaksanaan kebijakan harus didukung oleh sumberdaya-sumberdayayang mendukung agar pelaksanaannya berjalan dengan baik. Implementasi Program Beras sejahtera (Rastra) di Desa Mulyasari Kecamatan Pamanukan Kabupaten Subang dalam indkator sumber dayan yang digunakan belum optimal, karena kurangnya kompetensi dan tanggung jawab dari pelaksana program/

\section{Lingkungan Kebijakan (Contex of Policy)}

1. Kekuasaan, kepentingan-kepentingan dan strategi dari aktor yang terlibat.

Menurut Informan Pemerintah Kecamatan apa yang dilakukan oleh stakeholder kecamatan untuk mensukseskan program Rastra di Desa Mulyasari Kecamatan Pandeglang Kabupaten Subang tahun 2019. “Lebih meningkatkan pengawasan, dengan evaluasi dan monitoring'. Jadi pengawasan sangat baik dilakukan dalam impelementasi suatu kebij akan, sebuah kebij akan jika tidak diawasi akan menghasilkan program yang gagal. Jika program sudah berjalan, maka program tersebut harus dievaluasi, secara umum evaluasi kebij akan dapat dikatakan sebagai kegiatan yang menyangkut substansi dan implementasi dampak. Dalam hal ini evaluasi dipandang suatu kegiatan fungsional, artinya evaluasi kebijakan tidak hanya dilakukan pada tahap akhir saja melainkan dilakukan dalam seluruh proses kebijakan, dengan demikian evaluasi kebijakan bisa meliputi tahap perumusan masalah-masalah kebij aksanaan, program-program yang diusulkan untuk menyelesaikan masalah kebijakan, implementasi maupun tahap dampak kebijakan. Menurut Informan kecamatan, strategi apa yang dilakukan oleh Camat Pamanukan agar Desa Mulyasari dapat mengatasi keterlamabatan pembayaran Rastranya, agar pendistribusian Rastra di Desa Mulyasari Kecamatan Pamanukan Kabupaten Subang lancar. "Menerapkan kebijakan dan peraturan yang sudah ada, contohnya RTSPM harus membayar Rastranya dalam jangka 5 hari, mengikuti undang-undang yang sudah ada, ada batasan lmit waktu pembiayaan, adanya sanksi kepada desa yang 


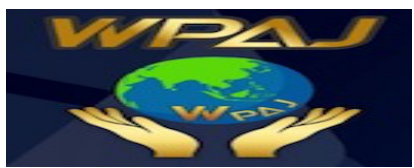

tidak mematuhi peraturan yang sudah dibuat".

Jadi yaitu alangkah baiknya jika yang menyimpan, dan memegang uang Rastra adalah orang yang jujur, amanah dan bisa dipercaya. Untuk menghindari hal-hal yang dapat merugikan desa dan RTSPM khususnya. Dialog dengan RT/RW dan masyarakat di lingkungan Desa Mulyasari bisa membuka jalan untuk mengetahui permasalahan-permasalahan apa saja yang ditemukan dilapangan dalam implementasi Beras sejahtera di wilayah Desa Mulyasari Kecamatan Pamanukan Kabupaten Subang.

Menurut Grindle, Dalam suatu kebijakan perlu dipertimbangkan pula kekuatan atau kekuasaan, kepentingan serta strategi yang digunakan oleh para actor yang terlibat guna memperlancar jalannya pelaksanaan suatu implementasi kebijakan. Jadi Implementasi Program Beras sejahtera (Rastra) di Desa Mulyasari Kecamatan Pamanukan Kabupaten Subang dalam indkator Kekuasaan, kepentingankepentingan dan strategi dari aktor yang terlibat.yang digunakan sudah optimal, karena didukung oleh seluruh stakeheolder desa mulyasari.

\section{Karakteristik Lembaga dan Rezim yang berkuasa}

Menurut Informan Pemerintah Kecamatan, bagaimana karakteristik Desa Mulyasari sehingga pembayaran Rastra di Desa Mulyasari terlambat. "Aparatur desa masih lemah dalam melaksanakan fungsi kontrol terhadap pelaksanaan program pemerintah/ Rastra." Sedangkan menurut Informan Masyarakat, tentang karakteristik masyarakat Desa Mulyasari adalah : "Antusias masyararakat terhadap Rastra yang digulirkan Pemerintah di Desa Mulyasari cukup bagus"

Jadi dari pernyataan tersebut diatas adalah sebagai pengambil keputusan, seorang pimpinan harus tegas dalam mengambil keputusan, mengontrol setiap program yang sedang berjalan dan tegas menerapkan peraturan kepada aparatur di lingkungan kerjanya.

Menurut Grindle, Lingkungan dimana suatu kebijakan tersebut dilaksanakanjuga berpengaruh terhadap keberhasilannya, maka pada bagian ini ingin dijelaskan karakteristik dari suatu lembaga yang akan turut mempengaruhi suatu kebijakan. Jadi Implementasi Program Beras sejahtera (Rastra) di Desa Mulyasari Kecamatan Pamanukan Kabupaten Subang dalam indkator Karakteristik Lembaga dan Rezim yang berkuasa sudah optimal, karena adanya ketegasan dari pemerintah sehingga beras sejahtera tepat sasaran.

\section{Tingkat Kepatuhan dan Adanya Respon dari Pelaksana}

Menurut Informan, bagaimana tingkat kepatuhan dan respon aparatur Desa Mulyasari dalam pelaksanaan program Rastra di wilayah Desa Mulyasari Kecamatan Pamanukan Kabupaten Subang pada tahun 2019, serta faktor pendukung dan penghambat program Rastra di Desa Mulyasari Kecamatan Pamanukan Kabupaten Subang tahun 2019. "Tingkat kepatuhan dan Respon pelaksana cukup balk, hanya masih terdapatnya ekonomi masyarakat RTSPM Desa Mulyasari yang kurang memadai". Jadi, jika dianalisa jawaban dari Kepala Desa Mulyasari tersebut menjelaskan bahwa penyebab keterlambatan pembayaran Rastra di wilayah Desa Mulyasari Kecamatan Pamanukan Kabupaten Subang pada tahun 2019 disebabkan oleh keadaan ekonomi masyarakatnya yang kekurangan, dan aparatur Desa 


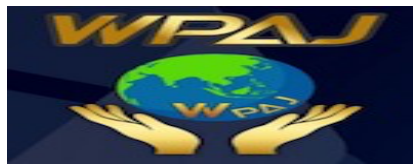

Mulyasarinya sudah bekerja dengan optimal, meskipun BOP untuk Rastra ini kecil hanya Rp. 6,- per kilogram.

Jadi Lokasi Desa Mulyasari cukup mendukung, jika Rastra diminati masyarakat Desa Mulyasari diharapkan juga dalam pembayaran Rastranya, karena jika implementasi Program Rastra di Desa Mulyasari tidak tepat sasaran dan tidak sesuai dengan tujuan pemerintah, sudah dipastikan Program Rastra tersebut tidak berhasil. Menurut wawancara, mengenai faktor penghambat impelemntasi Rastra di Wilayah Desa Mulyasari Kecamatan Pamanukan Kabupaten Subang tahun 2018 adalah : "Masih ditemukan beras dengan kualitas rendah, kesadaran masyarakat untuk membayar masih ada yang kurang, factor ekonomi yang lemah, RTSPM berasal dari kalangan menengah ke bawah". Jadi : dari pernyataan di atas adalah kualitas beras yagn diterima RTSPM mempengaruhi pembayaran dari RTSPM, karena kualitas beras yang rendah RTSPM menjadi malas membayar. Perum Bulog agar lebih meningkatkan kualitas beras Rastra yang dijual kepada RTSPM ini. Karena berdasarkan hasil wawancara dengan RTSPM RW 05 Dsn Kedung Gede mereka sering menerima beras Rastra dengan kualitas yang rendah, berikut hasil wawancaranya : Informan Masyarakat menyatakan bahwa : "Beras yang didistribusikan harus beras yang bagus jangan yang berbau apek, berkutu dan berwarna kuning. Kepada Bapa Presiden dimohon untuk memberi perhatian kepada kualitas beras sejahtera yang didistribusikan oleh Bulog, karena pada tahun 2019 Rastra tersebut berbau apek, berkutu dan berwarna kuning. Hal ini harus diperhatikan dalam rangka meningkatkan taraf hidup dan kesehatan warga miskin ". Dari pernyataan di atas jadi adalah masyarakat RTSPM sangat mengahrapkan kualitas Rastra diperbaiki karena yang selama ini terjadi mereka sering menerima Rastra dengan kualitas sangat rendah dan tidak layak dikonsumsi. Perum Bulog harus mementingkan kesejahteraan masyarakat juga, tidak hanya mementingkan keuntungan perusahaannya.

Untuk menjawab rumusan masalah yang penulis ajukan dalam penelitian ini yaitu bagaimana implementasi Program Beras Mi skin (Rastra) di Desa Mulyasari Kecamatan Pamanukan Kabupaten Subang tahun 2019. Yang mana hasil wawancara dengan informan yang terkait dengan implementasi Rastra di Desa Mulyasari seperti Camat Pamanukan, Kepala Desa Mulyasari, Staf Kesos Kecamatan, Ketua RW 07 Dsn Bojong Curug, Ibu RW 05 Cikaung dan Ketua Kertajaya, RTSPM RW 07 Dsn Bojong Curug, RTSPM RW 05 Dsn Kedung Gede, RTSPM RW 14 Dsn Lumbung dan keberhasilan Program Rastra diukur berdasarkan tingkat pencapaian indikator 6 Tepat (6T) yaitu Tepat Sasaran, Tepat Jumlah, Tepat Harga, Tepat Waktu, Tepat Kualitas, dan Tepat Administrasi maka kesimpulan penulis adalah bahwa Implementasi Rastra tersebut belum sesuai dengan tujuan, implementasi Program Rastra di Desa Mulyasari Kecamatan Pamanukan Kabupaten Subang belum dapat berjalan dengan baik seperti apa yang diharapakn dari tujuan kebijakan tersebut.

Dari hasil akhir penelitian tersebut kita dapat melihat kembali teori yang dikemukakan oleh Merilee S. Grindle dalam Agustino (2006:154) yang menyatakan bahwa : "Pengukuran keberhasilan implementasi dapat dilihat dari prosesnya, dengan mempertanyakan apakah pelaksanaan program sesuai dengan yang telah ditentukan, yaitu melihat pada action program dari individu projects dan yang kedua apakah tujuan program tersebut tercapai". Dari teori yang dikemukakan oleh Grindle 


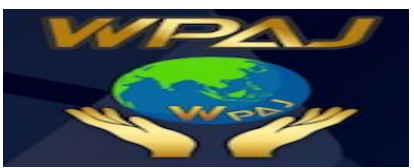

tersebut peneliti dapat menjelaskan mengenai implementasi Program Beras sejahtera (Rastra) di Desa Mulyasari Kecamatan Pamanukan Kabupaten Subang tahun 2018, dimana dalam teori tersebut indikator yang terpenting dalam melihat keberhasilan dari suatu kebijakan tersebut adalah dengan melihat bagaimana proses implementasi tersebut, begitu juga dalam Implementasi Program Rastra di Desa Mulyasari Kecamatan Pamanukan Kabupaten Subang tahun 2018 harus melihat bagaimana proses implementasi tersebut, apakah pelaksanaannya sudah sesuai dengan program/aturan yang telah ditentukan. Selain itu Grindle juga dalam Agustino (2006:168) menyatakan bahwa keberhasilan implementasi dari suatu kebijakan amat ditentukan oleh tingkat implementasi itu sendiri, yang terdiri dari content of policy (Isi Kebijakan) dan Context of Policy (lingkungan kebijakan).

Berdasarkan analisis mengenai implementasi Program Beras sejahtera (Rastra) di Desa Mulyasari Kecamatan Pamanukan di atas, menurut Jadi bahwa implementasi Program Rastra di Desa Mulyasari proses pelaksanaan program telah sesuai dengan mekanisme perencanaan dan pelaksanaan yang diberikan oleh pemerintah pusat melalui menteri perekonomian dan kesejahteraan rakyat, dan dituangkan dalam Buku Petunjuk Teknis atau Buku Pedoman Rastra yang telah dipaparkan oleh penulis. Secara teknis proses pelaksanaan, pendistribusian Rastra di Desa Mulyasari sudah sesuai dengan aturan yagn ditentukan namun pelaksanaan pembayararanRTSPM-nya mengalami keterlambatan pembayaran, hambatannya yaitu dari faktor ekonomi RTSPM yang rendah.

Implementasi Program rastra di Desa Mulyasari diukur oleh Tingkat Implementasi Content of Policy yaitu isi kebijakan dan context ofpolicy yaitu lingkungan kebijakan. Untuk isi kebijakan sendiri yang terdiri dari kepentingan yang mempengaruhi, tipe manfaat, deraj at perubahan yang dicapai menurut peneliti sudah sesuai, dan dapat dijadikan pendukung dalam suatu kebijakan untuk diimplementasikan, hanya saja untuk indikator letak pengambilan keputusan, sumber daya yang digunakan strategi dari aktor yang terlibat, karakteristik lembaga dan rezim yang berkuasa, serta tingkat kepatuhan dan respon dari pelaksana menurut penulis belum cukup mendukung terhadap implementasi tersebut.

Berdasarkan hasil wawancara dengan informan penelitian Implementasi Program rastra di Desa Mulyasari Kecamatan Pamanukan yaitu Camat Pamanukan Hj. Nuriah, M.Si., Kabupaten Subang tahun 2019 unsur kepentingan dalam implementasi ini adalah melaui isu strategis pengentasan kemiskinan. Secara politikalnya mengacu pada visi dan misi Kabupaten Subang, tujuannya adalah kesejahteraan rakyat. Indikator tipe manfaat sudah sesuai dan dapat dijadikan pendukung dalam implementasi karena program Rastra ini sangat dirasakan manfaatnya oleh RTSPM di Desa Mulyasari dengan digulirkannya Program rastra ini ada perubahan yang dirasakan oleh Rumah Tangga Miskin, yaitu kesejahteraan mereka terbantu, sedangkan untuk indikator yang lain hanya RTSPM Kertajaya yang belum merasakan kesejahteraan dari Program Rastra tersebut, berdasarkan wawancara dengan Camat Pamanukan yaitu letak pengambilan keputusan Desa Mulyasari dinilai masih lemah dalam mengambil keputusan. Begitu juga mengenai sumber daya yang digunakan, aparatur Desa Mulyasari tidak taat peraturan dalam menjalankan tugasnya selaku Pelaksana Distribusi Rastra, Desa Mulyasari belum mengupayakan strategi untuk mengatasi permasalahan-permasalahan pembayaran 


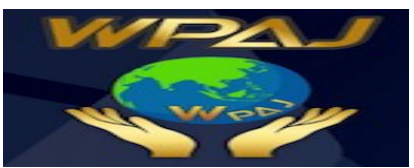

dari RTSPM-nya, untuk indikator karakteristik lembaga dan rezim yang berkuasa Desa Mulyasari masih lemah dalam menegakan fungsi kontrol terhadap Pelaksanaan Program Pemerintah, tidak tegas dan lemah dalam menerapkan aturan kepada aparatur diDesa Mulyasari sampai ke tingkat RT. Dan untuk indikator tingkat kepatuhan dan respon dari pelaksanaan menurut wawancara dengan Kepala Desanya cukup baik.

Menurut jadi apa yang dikemukakan oleh Grindle memang benar, bahwa keberhasilan implementasi tersebut amat ditentukan oleh tingkat implementaasinya. Baik dari isi kebijakan mapun dari lingkungan kebijakan itu sendiri. Dimana baik isi maupun dari lingkungan kebijakan tersebut harus menjadi pendukung dari sebuah implementasi kebijakan dalam upaya untuk tercapainya tujuan yang diharapkan dari kebijakan itu sendiri. Implementasi Program Rastra di Desa Mulyasari Kecamatan Pamanukan Kabupaten Subang tahun 2019 pada dasarnya baik isi maupun dari lingkungan kebijakan itu sendiri beberapa indikator sudah cukup mendukung tapi ada beberapa indikator yang belum mendukung, sehingga beberapa indikator yang kurang mendukung tersebut menjadi penghambat bagi kelancaran implementasi tersebut. Dimana implementasi program rastra di Desa Mulyasari Kecamatan Pamanukan Kabupaten Subang tahun 2019 belum berjalan seperti yang diharapkan.

\section{Kesimpulan}

Implementasi Program Beras sejahtera (Rastra) di Desa Mulyasari Kecamatan Pamanukan Kabupaten Subang belum berjalan dengan optimal seperti yang diharapkan, dengan dimesi sebagai berikut :

1. Pada dimensia isi Kebijakan (Content of Policy), implementasi Program Beras sejahtera (Rastra) di Desa Mulyasari Kecamatan Pamanukan Kabupaten Subang dalam indkator kepentingan yang mempengaruhi telah opimal karena tidak tunggangi oleh kepentingan perorangan melain suatu cita-cita dalam pengetansan kemiskinan kemudian pada indkator tipe manfaat telah optimal karena masyarakat target program meresa terbantu dengan adanya program ini, indkator derajat perubahan yang ingin dicapai belum optimal, karena untuk menghindari konflik social di masyarakat maka pemerintah desa dan jajaran membagi rata beras rastra tersebut sehingga jumlah beras yang dibagikan tidak sesuai dengan jumlah yang ditentukan pemerintah. Selanjutnya implementasi Program Beras sejahtera (Rastra) di Desa Mulyasari Kecamatan Pamanukan Kabupaten Subang dalam indkator letak pengambilan keputusan dicapai belum optimal karena pemerintah belum mampu mengatasi keterlambatan pembayaran beras sejahtera dan indkator pelaksana program belum optimal, karena petugas pelaksana program tidak mengantisipasi pembayaran yang macet dari program beras sejahtera, serta terakhir Implementasi Program Beras sejahtera (Rastra) di Desa Mulyasari Kecamatan Pamanukan Kabupaten Subang dalam indkator sumber dayan yang digunakan belum optimal, karena kurangnya kompetensi dan tanggung jawab dari pelaksana program/

2. Kemudian pada dimensi Lingkungan Kebijakan (Contex of Policy), Implementasi Program Beras sejahtera (Rastra) di Desa Mulyasari Kecamatan Pamanukan Kabupaten Subang dalam indkator Kekuasaan, kepentingan-kepentingan dan 


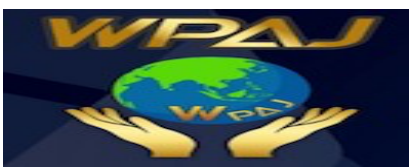

strategi dari aktor yang terlibat.yang digunakan sudah optimal, karena didukung oleh seluruh stakeheolder desa mulyasari, indkator Karakteristik Lembaga dan Rezim yang berkuasa sudah optimal, karena adanya ketegasan dari pemerintah sehingga beras sejahtera tepat sasaran serta masyarakat sering menerima Rastra dengan kualitas sangat rendah dan tidak layak dikonsumsi.

\section{Referensi}

Arikunto, Suharsimi. 2002. Prosedur Penelitian Suatu Pendekatan Penelitian. Jakarta: Rineka Cipta

Ekowati, Lilik. 2005. Perencanaan, Implementasi dan Evaluasi atau Program. Surakarta. Pustaka Cakra

Islamy, Irfan. 2000. Prinsip-Prinsip Perumusan Kebijaksanaan Negara. Jakarta: Bumi Aksara

Kementrian Koordinator Bidang Kesejahteraan Rakyat. 2009. Pedoman Umum Beras Untuk Rumah Tangga Miskin. Jakarta

Muhammad, Abdulkadir. 2007. Metodologi Penelitian. Bandung: Citra Aditya

Nawawi, Hadari. 2003. Metode Penelitian Bidang Sosial. Yogyakarta: Gajah Mada University Press

Nugroho, Riant. 2003. Kebijakan Publik, Formulasi, Implementasi, dan Evaluasi. Jakarta: PT Elex Media Komputindo

Pemerintah Desa Mulyasari Kecamatan Pamanukan, Kabupaten Subang.

Siagian, Sondang. 1983.Administrasi Pembangunan. Jakarta: CV Haji Masagung

Soekanto, Soejono. 1997. Pengantar Metodologi Penelitian. Jakarta: PT Raja Grafmdo Persada

Soetomo. 2006. Strategi-strategi Pembangunan Masyarakat. Yogyakarta: Pustaka Pelajar

Subarsono, AG. 2005. Analisis Kebijakan Publik. Konsep, Teori, dan Aplikasi. Yogyakarta: Pustaka Pelajar

Surachmad, Winamo. 1978. Dasar dan Teknik Research, Pengantar Metodologi I/miah. Bandung : Tarsi to.

Thoha, Miftah. 2002. Dimensi-Dimensi Prima Ilmu Administrasi Negara. Jakarta: PT Raja Grafmdo Persada

Undang-undang No. 11 Tahun2009.

Wahab, Abdul. 2004. Analisis Kebijakan dari Formula Keimplementasian Kebijakan Negara. Jakarta: Bumi Aksara

Wibawa, Samudra. 1994. Evaluasi Kebijakan Publik. Jakarta: PT Grafmdo Persada.

Yashin, Sulcahn. 1997. Kamus Lengkap Bahasa Indonesia (KBI-Besar) serta Ejaan Yang Disempumakan Dan Kosa Kata Bam. Surabaya. Amanah 